\title{
Consumer Engagement with Brand Posts on Social Media: Current State and Research Agenda
}

\author{
Qi Deng \\ Dalhousie University \\ Qi.Deng@dal.ca
}

\author{
Michael Hine \\ Carleton University \\ mike.hine@carleton.ca
}

\author{
Shaobo Ji \\ Carleton University \\ shaobo.ji@carleton.ca
}

\author{
Yun Wang \\ Carleton University \\ yun.wang3@carleton.ca
}

\begin{abstract}
Social media has become an integral part of the marketing communication mix and has changed the way that brands and consumers engage with each other. To marketers, consumer engagement with brand posts on social media is crucial because it is essential for creating social contagion effects and positively impacts consumers' perceptions of brand. However, social media marketers are struggling with approaching the creative brand contents in a way that maximizes consumer engagement. In academia, while some research suggests that marketers can strategically design brand contents that improve consumer engagement, it is not clear what contents work better, for which brand, and in what way. This paper presents a review of previous literature on consumer engagement with brand social media posts. Through the literature review, this paper summarizes the factors that are found to impact consumer engagement with brand social media posts. As such, this paper identifies several research streams which can be pursued.
\end{abstract}

\section{Introduction}

The proliferation of social media has changed the way that brands and consumers engage with each other [1]. Unlike traditional one-way communication (e.g., advertising on TV), social media provides a platform where brands and consumers can engage with each other in a bi-directional way [2-3]. For example, brands may create fan pages (e.g., Facebook brand pages, etc.) and microblogging accounts (e.g., Twitter, Instagram, etc.) and interact with consumers through regularly updating attractive posts, and consumers could follow the pages or accounts in accordance with their interests and actively interact with brands through engaging with (i.e., liking, sharing, or commenting on) these posts. Brand posts thus become a critical medium that connect brands and consumers. For marketers, consumer engagement with brand posts is crucial because it is essential for creating social contagion effects, whereby a brand's message reaches non-subscribers or those not participating in a conversation with the brand [4]. Research has also shown that consumer engagement with brand posts is positively related with: brand awareness, preference, and consideration [3, 5-7]; brand equity [8]; and brand performance (e.g., sales, new customer acquisition, value, etc.) $[3,7,9]$.

Despite the importance of consumer engagement, research reported that only about $1 \%$ of a brand's followers on Facebook engage with the brand posts [10]. Even within the biggest Facebook brand pages, the fan engagement rate is only $4.3 \%$ [11]. Social media marketers are struggling with approaching the creative brand posts in a way that maximizes consumer engagement. This has resulted in many social media efforts being experimental trial and errors that rarely result in the desired outcome [12]. Therefore, understanding how to design brand posts that induce active consumer engagement is deemed an important priority [13]. While some research suggests that marketers can strategically design brand posts that improve consumer engagement, it is still not clear what content works better, for which brand, and in what way [10]. More research is needed to reveal how to develop and implement engaging brand posts on social media [14-15].

The purpose of this paper is twofold. First, we aim to conduct a review of extant literature on consumer engagement with brand posts on social media (CEBPSM). Second, through reviewing the extant literature, we identify some potentially fruitful research agendas to explore. This paper has several implications. First, it provides some practical guidelines on how to design brand posts to enhance consumer engagement. Second, the results of this paper portray a big picture of the current research on consumer engagement with brand posts on social media as well as reveal agendas that could be addressed in future research. The rest of this paper is organized as follows. Section 2 presents the research methodology used in this paper. Section 3 presents the results of the literature review. Section 4 discusses some research agendas that could be addressed in the future. Section 5 provides a conclusion. 


\section{Methodology}

To identify previous research that addressed CEBPSM, we first conducted a literature search within two databases: 1) Business Source Complete; 2) Web of Science Core Collection. Specifically, we searched the databases to identify the academic papers of which the abstracts include "brand post/message/content popularity" or "brand post/message/content AND consumer engagement" and that were written in English. This step resulted in 107 papers. After deduplication, we secured 85 papers. We read through the titles and abstracts of the 85 papers and removed both unrelated papers and conceptual papers. Our review only focused on empirical papers because they provide information in terms of both research design and data-supported research results. This step resulted in 12 empirical papers that directly addressed the topic of CEBPSM. To extend our review sample, we adopted a snowball sampling method and searched for related research cited by the 12 papers. We also searched Google Scholar using the same search keywords. After the same screening process, this step resulted in 5 additional papers. Our final review sample includes 17 papers.

\section{Previous Research on Consumer Engagement with Brand Posts on Social Media}

Consumer engagement with brand posts on social media has been empirically studied in previous research under many conceptualizations (e.g., brand post popularity, brand content popularity, message popularity, user interaction, consumer engagement, and consumer involvement, etc.), being operationalized using different measurements (e.g., number of like/comment/share, like/comment/share rations to impression, and other variables calculated from number of like/comment/share, etc.), and within a variety of contexts (e.g., single/multiple industries, B2B/B2C, product/service, etc.) (see 5, 6, 8, 10, 13, 14, 16-26). Slightly differing in the research design (e.g., sample size and variable operationalization), previous research is mainly rooted in traditional advertising literature and marketing communication theory and dependent on the field study method that uses manual content analysis to analyze data collected from Facebook brand pages. A summary of previous research can be found in Table 1 . Notably, we use superscripts to indicate the results of hypotheses testing, specifically, "S" means support, "NS" means not support, and "PS" means partially support. For example, "Vividness — Like S, Comment NS" in the first row means that the hypothesis that the vividness of brand post significantly impacts the number of likes (comments) is supported (not supported).

Table 1. Previous research on CEBPSM

\begin{tabular}{|c|c|c|c|}
\hline Source & Method & Data & Findings* \\
\hline $\begin{array}{l}\text { de Vries, } \\
\text { Gensler, \& } \\
\text { Leeflang } \\
{[17]}\end{array}$ & Field study & $\begin{array}{ll}\text { - } & \text { Facebook; } 355 \\
\text { brand posts } \\
\text { - } & 11 \text { international } \\
\text { brands across } 6 \\
& \text { product categories } \\
\text { - } & \text { May 24, 2010- } \\
& \text { Feb. 18, 2011 }\end{array}$ & $\begin{array}{l}\text { Post Content } \\
\text { - Information - Like }{ }^{\mathrm{NS}}, \text { Comment }{ }^{\mathrm{NS}} \\
\text { - Entertainment - Like }{ }^{\mathrm{NS}}, \text { Comment }{ }^{\mathrm{NS}} \\
\text { Post Media } \\
\text { - Vividness - Like }{ }^{\mathrm{S}} \text {, Comment }{ }^{\mathrm{NS}} \\
\text { - Interactivity - Like }{ }^{\mathrm{PS}}, \text { Comment }{ }^{\mathrm{PS}} \\
\text { Valence of comments } \\
\text { - Share of positive comments - Like }{ }^{\mathrm{S}} \text {, Comment }{ }^{\mathrm{S}} \\
\text { - Share of negative comments - Like }{ }^{\mathrm{NS}}, \text { Comment }\end{array}$ \\
\hline $\begin{array}{l}\text { Swani, } \\
\text { Milne, \& } \\
\text { Brown [24] }\end{array}$ & Field study & $\begin{array}{ll}\text { Facebook; } 1146 \\
\text { brand posts } \\
\text { 280 Fortune } 500 \\
\text { companies } \\
\text { Mar. 29, 2011- } \\
\text { Apr. 4, 2011 }\end{array}$ & $\begin{array}{l}\text { (Brand type, i.e., B2B vs. B2C, as moderator) } \\
\text { Post Content } \\
\text { - Use of brand name - Like }{ }_{\mathrm{B} 2 \mathrm{~B}}>\mathrm{Like}_{\mathrm{B} 2 \mathrm{C}} \mathrm{s} \\
\text { - Use of emotional content }- \text { Like }_{\mathrm{B} 2 \mathrm{C}}>\mathrm{Like}_{\mathrm{B} 2 \mathrm{~B}} \mathrm{NS} \\
\text { - Use of direct call }- \text { Like }_{\mathrm{B} 2 \mathrm{C}}>\text { Like }_{\mathrm{B} 2 \mathrm{~B}} \mathrm{NS}^{-}\end{array}$ \\
\hline $\begin{array}{l}\text { Swani \& } \\
\text { Milne [25] }\end{array}$ & Field study & $\begin{array}{ll}\text { - } & \text { Facebook; } 1467 \\
\text { brand posts } \\
\text { - } \\
\text { 213 Fortune } 500 \\
\text { companies }\end{array}$ & 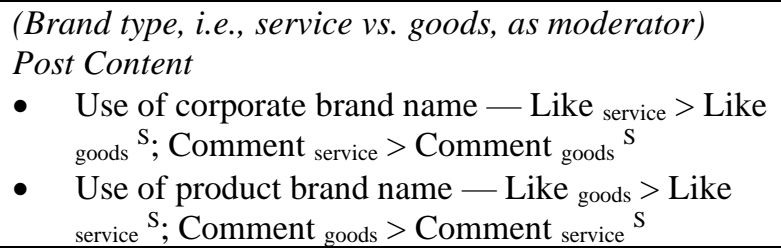 \\
\hline
\end{tabular}




\begin{tabular}{|c|c|c|c|}
\hline & & $\begin{array}{l}\text { - The week of Sept. } \\
29,2011\end{array}$ & 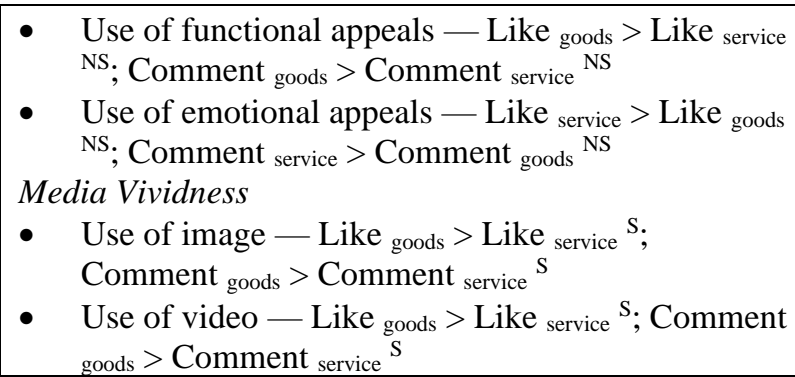 \\
\hline $\begin{array}{l}\text { Swani et al. } \\
{[26]}\end{array}$ & Field study & $\begin{array}{l}\text { - Facebook; } 1498 \\
\text { brand posts } \\
10 \text { automobile } \\
\text { brands } \\
\text { - May } 2013-\text { Oct. } \\
2014\end{array}$ & 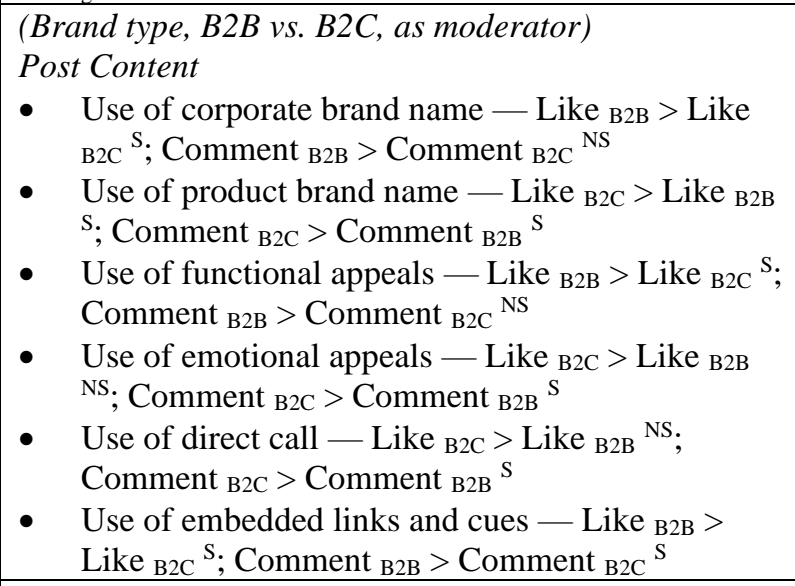 \\
\hline $\begin{array}{l}\text { Coursaris, } \\
\text { van Osch, \& } \\
\text { Balogh [5] }\end{array}$ & $\begin{array}{l}\text { Field study; } \\
\text { Multi-case } \\
\text { study }\end{array}$ & $\begin{array}{ll}\text { Facebook; } 369 \\
\text { brand posts } \\
\text { - } 3 \text { selected brands } \\
\text { (Delta Airline, } \\
\text { Walmart, \& } \\
\text { McDonald's) } \\
\text { Two 6-week periods } \\
\text { of data collection }\end{array}$ & $\begin{array}{l}\text { Post Content } \\
-\quad \text { Transformational message appeal — engagement } \\
\mathrm{s} \\
\text { Post Media } \\
-\quad \text { Message richness — engagement } \mathrm{s}\end{array}$ \\
\hline $\begin{array}{l}\text { Wagner, } \\
\text { Baccarella, } \\
\& \text { Voigt }[8]\end{array}$ & Field study & $\begin{array}{l}\text { Facebook; } 1948 \\
\text { brand posts } \\
10 \text { automobile } \\
\text { brands } \\
\text { May } 2013 \text { - Oct. } \\
2014 \\
\end{array}$ & $\begin{array}{l}\text { Post Content } \\
\text { - } \begin{array}{l}\text { Message emotional appeals - Like } \\
\text { PS, Share }\end{array} \text { Comment } \\
\text { - }{ }^{\mathrm{PS}} \\
\text { Message utilitarian appeals }- \text { Like }^{\mathrm{PS}} \text {, Share }{ }^{\mathrm{PS}} \text {, } \\
\text { Comment }^{\mathrm{PS}}\end{array}$ \\
\hline $\begin{array}{l}\text { Gutiérrez- } \\
\text { Cillán, } \\
\text { Camarero- } \\
\text { Izquierdo, \& } \\
\text { San José- } \\
\text { Cabezudo } \\
{[18]}\end{array}$ & Survey & $\begin{array}{ll}\text { Online } \\
\text { questionnaire; } 252 \\
\text { responses } \\
\text { - Fans in a Spanish } \\
\text { women's fashion } \\
\text { brand's Facebook } \\
\text { fan page } \\
\end{array}$ & $\begin{array}{l}\text { Post Content } \\
\text { - Information posts - engagement } \mathrm{s} \\
\text { - } \quad \text { Image posts - engagement }{ }^{\mathrm{NS}} \\
-\quad \text { Interaction posts - engagement }^{\mathrm{NS}}\end{array}$ \\
\hline $\begin{array}{l}\text { Cruz, } \\
\text { Leonhardt, } \\
\text { \& Pezzuti } \\
{[6]}\end{array}$ & Field study & 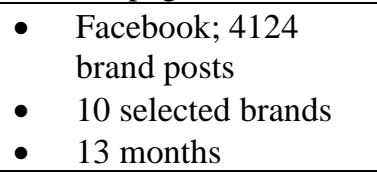 & $\begin{array}{l}\text { Post Content } \\
-\quad \text { Use of the second pronoun — engagement } \mathrm{s}\end{array}$ \\
\hline $\begin{array}{l}\text { Luarn, Lin, } \\
\& \text { Chiu [21] }\end{array}$ & Field study & $\begin{array}{l}\text { - Facebook; } 1030 \\
\text { brand posts } \\
\text { - } 10 \text { most popular } \\
\text { brands on Facebook }\end{array}$ & $\begin{array}{l}\text { Post Content } \\
\text { - Content type (informational, entertainment, } \\
\text { remuneration, \& social) - Like }{ }^{\mathrm{s}} \text {, Share }{ }^{\mathrm{s}} \text {, } \\
\text { Comment } \mathrm{s} \\
\text { Post Media }\end{array}$ \\
\hline
\end{tabular}




\begin{tabular}{|c|c|c|c|}
\hline & & $\begin{array}{ll} & \text { Mar. 1,2014- May } \\
& 1,2014\end{array}$ & $\begin{array}{ll}\text { - } & \text { Vividness - Like }{ }^{\mathrm{PS}} \text {, Share }{ }^{\mathrm{PS}} \text {, Comment }{ }^{\mathrm{PS}} \\
\text { - } & \text { Interactivity - Like }{ }^{\mathrm{S}} \text {, Share }{ }^{\mathrm{S}}, \text { Comment }^{\mathrm{S}}\end{array}$ \\
\hline $\begin{array}{l}\text { Kim, Spiller, } \\
\text { \& Hettche } \\
{[13]}\end{array}$ & Field study & $\begin{array}{l}\text { - Facebook; } 1086 \\
\text { brand posts } \\
\text { - } 100 \text { brands in the } \\
\text { Best Global Brands } \\
2012 \\
\text { - July } 2013\end{array}$ & $\begin{array}{l}\text { Post Content } \\
\text { - Content orientation (task-oriented, interaction- } \\
\text { oriented, \& self-oriented) - Like }{ }^{\mathrm{s}} \text {, Share }{ }^{\mathrm{s}} \text {, } \\
\text { Comment }{ }^{\mathrm{s}} \\
\text { Post Media } \\
\text { - Media type (text-photo, text-video, photo-video) } \\
\quad-\text { Like }^{\mathrm{s}}, \text { Share } \mathrm{s}, \text { Comment } \\
\mathrm{s}\end{array}$ \\
\hline $\begin{array}{l}\text { Cvijikj \& } \\
\text { Michahelles } \\
{[16]}\end{array}$ & Field study & $\begin{array}{l}\text { Facebook; } 5035 \\
\text { brand posts } \\
10 \text { fast-moving } \\
\text { consumer goods } \\
\text { brands } \\
\text { Jan. } 2012-\text { Mar. } \\
2012\end{array}$ & 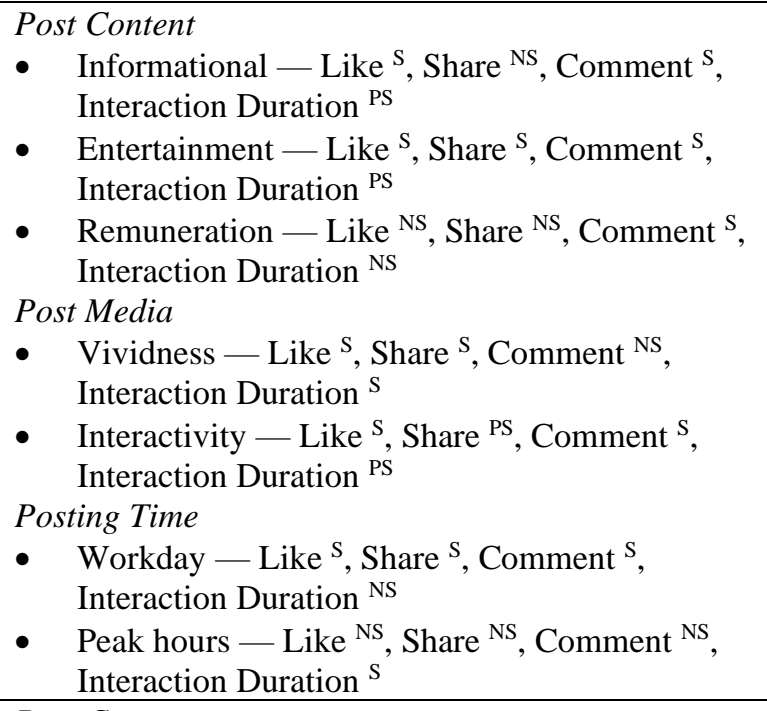 \\
\hline $\begin{array}{l}\text { Lee, } \\
\text { Hosanagar, } \\
\& \text { Nair [10] }\end{array}$ & Field study & $\begin{array}{l}\text { - } \quad \text { Facebook; } 106316 \\
\text { brand posts } \\
\text { - } 782 \text { companies } \\
\text { across } 6 \text { industries }\end{array}$ & $\begin{array}{l}\text { Post Content } \\
\text { - Brand-personality related content }- \text { Like }^{\mathrm{s}}, \\
\text { - } \text { Comment }^{\mathrm{s}} \\
\text { Directly informative content }- \text { Like }^{\mathrm{s}} \text {, Comment } \\
\text { - } \quad \text { Message length }- \text { Like }^{\mathrm{s}}, \text { Comment } \mathrm{s} \\
\text { - } \quad \text { Brand-personality related content } \times \text { Directly } \\
\text { informative content }- \text { Like }{ }^{\mathrm{s}}, \text { Comment } \mathrm{s}\end{array}$ \\
\hline $\begin{array}{l}\text { López et al. } \\
{[14]}\end{array}$ & Experiment & $\begin{array}{l}\text { - Online experiment; } \\
369 \text { participants } \\
\text { - Fans in a Spanish } \\
\text { women's fashion } \\
\text { brand's Facebook } \\
\text { fan page }\end{array}$ & 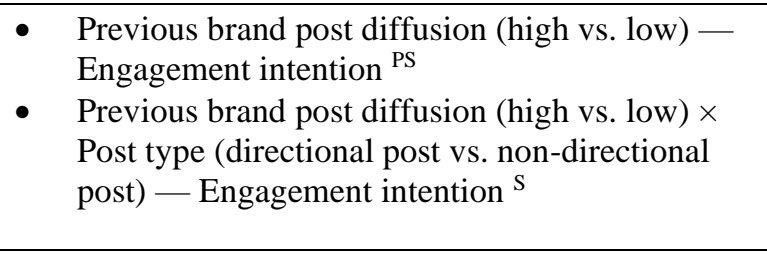 \\
\hline $\begin{array}{l}\text { Sabate et al. } \\
{[22]}\end{array}$ & Field study & $\begin{array}{l}\text { - Facebook; } 164 \\
\text { brand posts } \\
\text { - } 5 \text { Spanish travel } \\
\text { agencies } \\
\text { - Mar. 21, 2011- } \\
\text { Apr. 21, 2011 }\end{array}$ & $\begin{array}{l}\text { Post Media } \\
\text { - } \quad \text { Images - Like }{ }^{\mathrm{s}} \text {, Comment }{ }^{\mathrm{s}} \\
\text { - } \quad \text { Videos - Like }{ }^{\mathrm{s}}, \text { Comment }{ }^{\mathrm{NS}} \\
\text { - } \quad \text { Links - Like }{ }^{\mathrm{N}}, \text { Comment } \\
\text { Posting Time } \\
\text { - } \quad \text { Weekday - Like }{ }^{\mathrm{NS}}, \text { Comment }^{\mathrm{NS}} \\
\text { - } \quad \text { Business hours - Like }{ }^{\mathrm{NS}}, \text { Comment }^{\mathrm{s}}\end{array}$ \\
\hline $\begin{array}{l}\text { Lei, Pratt, \& } \\
\text { Wang [20] }\end{array}$ & Field study & $\begin{array}{ll} & \text { Facebook; } 600 \\
\text { brand posts } \\
\text { - } & 6 \text { integrated resorts } \\
& \text { in Macau } \\
\text { - } & \text { Sept. } 2014-\text { Sept. } \\
& 2015 \\
\end{array}$ & 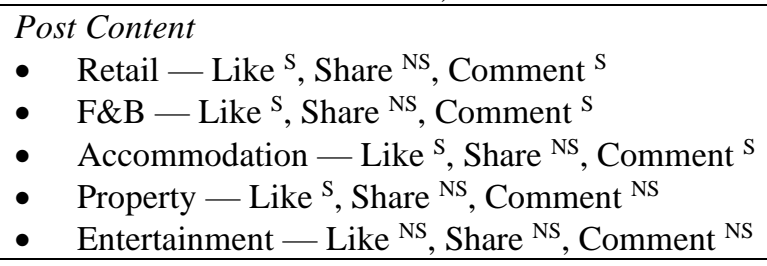 \\
\hline
\end{tabular}




\begin{tabular}{|c|c|c|c|}
\hline & & & 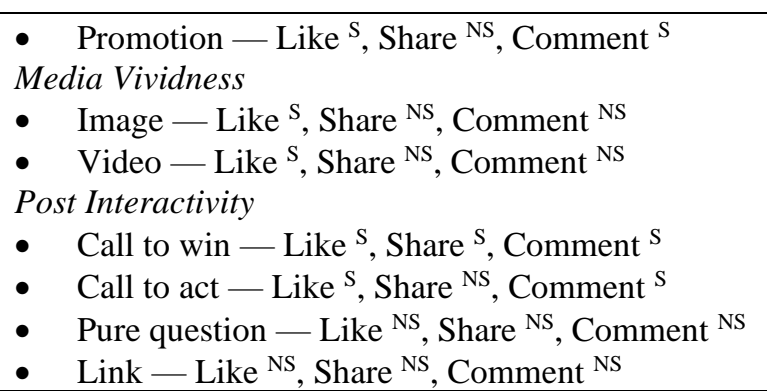 \\
\hline $\begin{array}{l}\text { Kwok \& Yu } \\
\text { [19] }\end{array}$ & Field study & $\begin{array}{ll}\text { - } & \text { Facebook; } 982 \\
\text { brand posts } \\
\text { - } 10 \text { chain restaurant } \\
\& 2 \text { independent } \\
\text { restaurant } \\
\text { - } \begin{array}{l}\text { Oct. } 2010-\text { Dec. } \\
\text { 2010 (every two } \\
\text { weeks) }\end{array} \\
\end{array}$ & $\begin{array}{l}\text { Post Content } \\
\text { - Content type (sales and marketing, conversation) } \\
- \text { Like }{ }^{\mathrm{NS}}, \text { Comment } \mathrm{s} \\
\text { Post Media } \\
\text { - Media type (status, link, photo, video) - Like }{ }^{\mathrm{s}} \text {, } \\
\quad \text { Comment } \mathrm{s}\end{array}$ \\
\hline Schultz [23] & Field study & $\begin{array}{ll}\text { - } & \text { Facebook; } 792 \\
\text { brand posts } \\
\text { - } \\
\text { 13 brands in } 2 \\
\text { industries (i.e., } \\
\text { apparel \& food } \\
\text { retailing) } \\
\text { - Apr. 14, 2014 - } \\
\text { May. 31, 2014 }\end{array}$ & $\begin{array}{l}\text { Post Content } \\
\text { - Content type (charity, competition, content, } \\
\text { coverage, holiday, human resources, products, } \\
\text { promotions, or statements) - Like }{ }^{\mathrm{PS}} \text {, Share }{ }^{\mathrm{PS}} \text {, } \\
\text { Comment }{ }^{\mathrm{PS}} \\
\text { Post Media } \\
\text { - } \quad \text { Vividness - Like }{ }^{\mathrm{PS}} \text {, Share }{ }^{\mathrm{PS}} \text {, Comment }{ }^{\mathrm{NS}} \\
\text { - Interactivity - Like }{ }^{\mathrm{PS}} \text {, Share }{ }^{\mathrm{PS}}, \text { Comment } \\
\text { Posting Time } \\
\text { - Top position - Like }{ }^{\mathrm{S}} \text {, Share }{ }^{\mathrm{S}} \text {, Comment }{ }^{\mathrm{S}} \\
\text { - } \quad \text { Weekday - Like }{ }^{\mathrm{NS}} \text {, Share }{ }^{\mathrm{NS}}, \text { Comment }{ }^{\mathrm{NS}}\end{array}$ \\
\hline
\end{tabular}

Generally, three factors that influence consumer engagement with brand posts on social media have been identified and empirically tested in previous research; namely, post content, post media, and posting time.

Post content refers to 'what' brands say. Previous research operationalized post content by categorizing post content type (e.g., informational, entertainment, remuneration, and social) or message appeal type (e.g., rational appeal, emotional appeal). Luarn, Lin, \& Chiu [21] found that consumers exhibit different levels of engagement with brand posts that are different content types. For example, people were more likely to like remuneration posts than information and entertainment posts and were more likely to comment on social and entertainment posts than information and remuneration posts. Similar effects of content types were also found in [16].

Post media refers to 'how' brands communicate. Previous research operationalized post media by categorizing the vividness (also named media richness in some research) and interactivity of brand posts. For example, in [17], vividness was coded into four levels, namely, 1) no vividness - posts with pure text, 2) low vividness - posts with photo or images, 3) medium vividness - posts with event, and 4) high vividness - posts with videos. Interactivity was coded into four levels, namely, 1) no interactivity - base category, 2) low interactivity - posts with link to a website or voting options, 3) medium interactivity - posts with calls to act or contests, and 4) high interactivity - posts with questions or quiz [17]. Through analysis, de Vries, Gensler, \& Leeflang [17] found that the vividness level of a brand post is positively related to the number of likes, and the high interactivity level of a brand post is negatively related to the number of likes but positively related to the number of comments. Using similar operationalization, Luarn, Lin, \& Chiu [21] found that consumers are more engaged (i.e., like, comment, share) with brand posts of high interactivity than medium and low interactivities.

Posting time refers to when brands communicate e.g., weekday/weekend [16-18, 20-23]. Cvijikj \& Michahelles [16] found that posting on workday can increase the number of comments but decrease the number of likes, and posting during the peak hours has a negative effect on the number of likes and shares. de Vries, Gensler, \& Leeflang [17] found that the number of days that a brand post is on top of the brand page is positively related to the number of likes and comments it receives. 
While previous research mainly focused on the characteristics of the posts per se, some further indicated that the relationship between brand post characteristics and consumer engagement is moderated by brand type (e.g., service vs. product, B2B vs. B2C, etc.) [24-26]. For example, Swani et al. [26] found that the use of brand names and rational message appeals have a higher number of likes and comments for B2B brand posts than B2C posts. Swani, Milne, \& Brown [24] found that emotional message appeals generate more likes in service brand posts than in product brand posts.
Our review revealed that previous research on CEBPSM was mainly adopting a stimuli-response model; that is, they only focused on investigating the relationship between characteristics of brand posts (the stimuli) and consumer engagement (the behavioral response) (see Figure 1). Because of this oversimplified base model, we propose that research on CEBPSM is still in its infancy and more research is needed. We identify four research streams that can be pursued by scholars interested in this field (see Figure 1) and will discuss these streams in the following section.
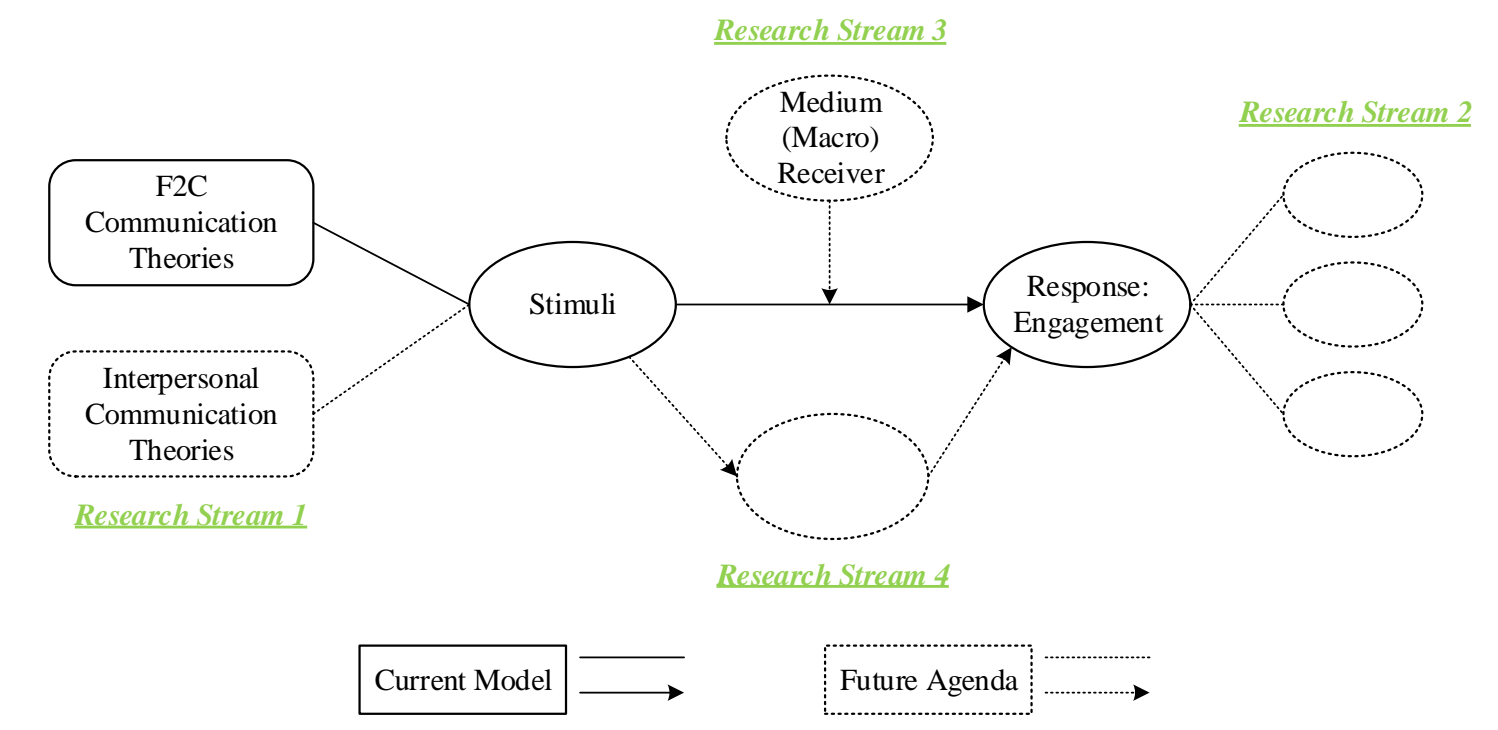

Figure 1. A conceptual roadmap for future research on CEBPSM

\section{Agenda for Future Research}

\section{Research Stream 1: Examine the Impacts of Brand Post Characteristics on Consumer Engagement}

Previous research on CEBPSM has shown a convergence on antecedent (i.e., brand post characteristics) selection. The review of previous research indicates that content type and media type (i.e., vividness and interactivity) are the two most widely studied antecedents of consumer engagement (see Table 1). The convergence in antecedent selection reveals some opportunities for future research on CEBPSM.

First, positioning this stream of research on a broader theoretical foundation could provide new insights for researchers. While previous research treated brand posts as firm-to-consumer (F2C) messages and was mainly dependent on the $\mathrm{F} 2 \mathrm{C}$ communication theories (e.g., advertising literature, marketing communication theories, etc.), interpersonal communication theories could also be employed to understand brand social media content strategy as the brand-consumer engagement on social media has a far more complicated structure than traditional F2C communication, and consumers tend to relate to brands the same way as they relate to people in general [see 13, 27]. Unlike traditional one-way carefully deliberated advertising communication that aims to promote sales, brand communication on social media is usually an open system that enables real-time, two-way, and more spontaneous brand-consumer engagement. [2]. Highly resembling interpersonal communication, brands encourage consumers to interact with them on social media in the same way they do with their friends and family [27]. Given this, consumers experience similar feelings to that of interpersonal interaction when they interact with brands on social media [28]. For example, based on the salesmanship literature, Kim, Spiller, \& Hettche [13] proposed a new method to categorize the content type of brand posts on social media and 
examined the current social media marketing practices of major global brands. Specifically, they classified the content type of brand posts into three categories, namely, task-oriented, interaction-oriented, and self-oriented and found that the content orientations have significant impacts on consumer engagement (i.e., the number of likes, comments, and shares) [13]. Drawing on role theory, Gretry et al. [2] investigated the impact of informal (vs. formal) communication style on consumers' brand trust in a social media context and found that informal communication style and brand familiarity jointly impact consumers' brand trust. Therefore, only focusing on F2C communication theories might miss some important characteristics of brand-consumer engagement on social media. Future research could embrace interpersonal communication theory to investigate effective social media content strategy further.

Second, more brand post characteristics could be examined. One possible direction could be drawn from research on emotion. Previous research has shown that the use of emotional appeals increases consumer engagement with brand posts, which implies that emotion incorporated in brand posts might play a role in impacting consumer engagement. Although previous research has rarely investigated the role of emotion, results from recent research suggest a promising research opportunity [10]. For example, emotion has been found to be related to the information sharing behavior (e.g., retweeting behavior, online content sharing, etc.) regarding both quantity and speed [29-30]. It has also been found to be an effective machine learning feature that can be used to predict consumer engagement with brand posts [10]. Thus, future research could examine the effects of emotion embedded in brand posts on consumer engagement.

\section{Research Stream 2: Re-consider the Consumer Engagement as a Multi-Dimensional, Multi- Faceted Concept}

Previous research has also shown a convergence on the operationalization of CEBPSM (see Table 1). As shown in Table 1, most of previous research operationalized consumer engagement with one brand post either by directly measuring the counts of likes, comments, and shares the post receives [see $8,10,13$, $17-18,20-26]$ or through creating a new variable that is calculated using these counts [see 5-6, 16, 19]. While research collecting data before 2012 only focused on the number of likes and comments, research after 2012 usually operationalized consumer engagement with brand posts with one additional measurement, i.e., the number of shares. The reason for this change might be that Facebook launched the "share" button in 2012, after which, the number of shares for brand posts became available to researchers. Therefore, it seems reasonable to assume that previous operationalization of consumer engagement with brand posts was a data-driven decision. This data-driven approach could cause problems since it ignores the fact that consumer engagement is a multidimensional and multi-faceted concept.

The concept of consumer engagement emerged in the literature around 2005 and has received a large amount of attention from researchers [31]. While there is no consensus on what consumer engagement is, much research on consumer engagement conceptualization has indicated that it is a multi-dimensional concept that is comprised of three dimensions; cognitive, emotional, and behavioral [32]. Despite its multi-dimensional perspective, consumer engagement is also a multifaceted concept. For example, within the behavioral dimension, consumer engagement with brand-related contents on social media has been proposed to be a continuum of three engagement types, i.e., consuming (e.g., viewing brand-related video, reading comments on social network sites, reading product reviews, etc.), contributing (e.g., rating products/brands, joining a brand profile on a SNS, engaging in branded conversations, commenting on brand-related weblogs, video, audio, pictures, etc.), and creating (e.g., publishing a brand-related weblog, writing product reviews or brand-related articles, uploading brandrelated video/pictures, etc.) [33]. Given the significant dependence on field study method and the limited availability of field data, most of the previous research on CEBPSM seems to treat consumer engagement as a uni-dimensional and uni-faceted concept and only consider its behavioral dimension with a focus on consumers' contributing behavior. Therefore, future research could employ other research methods (e.g., survey, experiment, etc.) and examine the cognitive and emotional dimensions and other facets (i.e., consuming and creating) of the behavioral dimension of consumer engagement. Furthermore, solely focusing on the perspective of quantity (e.g., number of likes, comments, and shares), previous research has proposed that researchers could also examine the valence of consumer engagement [4, 8, 25-26]. Considering the important role that positive sentiment plays in eWOM and currently available tools for sentiment analysis, future research could also explore the impact of brand content characteristics on the valence of consumer engagement (e.g., the sentiment of consumer comments, etc.).

\section{Research Stream 3: Investigate the Moderating Role of Medium and Consumer Characteristics}

While rooted in traditional marketing communication literature, previous research on CEBPSM did not adequately consider the elements in the marketing communication model. According to the 
marketing communication model, marketing communication is a process that a source encodes (or creates) and transmits a message through a medium, and then, a receiver receives and decodes (processes) the transmitted message [25, 34]. Thus, the result of the marketing communication is dependent on both how the source encodes and how the receiver decodes the message. Regarding a consumer's engagement with one brand post on social media, the source is the brand (or marketer), the message is the brand post, the medium is the media type (at the micro level, e.g., text, image, video, etc.) and social media platform (at the macro level, e.g., Facebook, Twitter, Instagram, etc.), and the receiver is the consumer. To properly understand the consumer engagement behavior (the communication result), one should take characteristics of posts (the message), brands (the source), medium type and social media platform (the medium), and consumers (the receiver) into account. Previous research on CEBPSM has mainly focused on the message (e.g., content type, message length, etc.), slightly addressed the source (e.g., B2B/B2C brand, product/service brand, PDI, etc.) and the medium (at the micro level, e.g., media type, etc.), and overlooked the receiver (see Table 1), which is contrary to the broad consensus that consumers being active participants in brand social media and might result in missing some important insights regarding the communication process and potential moderators regarding the communication result.

Previous research has indicated that online engagement varies across social media platforms and consumers. For example, Schweidel \& Moe [35] found that the sentiment expressed in social media venues vary across different venue formats (i.e., blog, forum, and microblog). Thus, data collected from only one type of social media platforms might be systematically biased. They further concluded that what people post is related to where they post. Hughes et al. [36] found that the preference for social media usage was associated with differences in personality. According to Hughes et al., people who see themselves as higher in sociability, extraversion, and neuroticism and lower in need-forcognition have a preference for Facebook, compared to Twitter. Khan et al. [37] found that the impacts of content type and media type of brand posts on consumer engagement vary across different cultures. Cruz, Leonhardt, \& Pezzuti [6] found that the relationship between second person pronouns usages in online brand messaging and consumer engagement is moderated by individual levels of collectivism. Specifically, the presence (vs. absence) of second person pronouns in online brand messaging increases engagement only for consumers that are lower (vs. higher) in collectivism. These findings suggest that characteristics of both platform and consumer can impact consumer engagement on social media. Previous empirical investigations into the impact of brand post characteristics on consumer engagement have shown some mixed or inconclusive results. For example, some researchers [14, 17] found that the higher the level of vividness of a brand post, the more likes the brand post will receive, while some [21] found that brand posts with a high level of vividness received fewer likes than posts with a medium level of vividness. While some did not find the impact of brand posts content type on consumer engagement [17], some did [16,21]. Given all of these research has a focus on Facebook, one possible explanation for these mixed findings is that they failed to take consumers' characteristics into account. Therefore, future research should consider the elements in marketing communication model simultaneously and explore the role that characteristics of social media platforms and consumers play in influencing consumer engagement with brand posts.

\section{Research Stream 4: Reveal the Mechanism between Stimuli and Behavioral Response}

Due to the dependence on the oversimplified base model, current understanding of consumer engagement with brand social media posts is at a very superficial level, that is, we know what (i.e., what brand post characteristics are related to consumer engagement), but we do not know why (i.e., why specific brand post characteristics can induce consumer engagement while others cannot). For example, we know that, to increase consumer engagement, the best media type of brand posts is a combination of text and image, but we do not know why this media type is mostly embraced by consumers. Many possible explanations have been proposed; for example, consumers might not like posts that require too much cognitive activity to understand $[17,21]$, however, none of these potential explanations has been empirically tested. As another example, previous research has shown that the three consumer engagement behaviors (i.e., liking, commenting, and sharing) had different determinates and proposed that future research should treat them differently and examine them separately. According to previous research, one possible reason for such difference is that liking, commenting, and sharing differ in the level of cognitive involvement and consumers performing which results in different visibility in one's personal network [14, 17, 22]. However, similarly, such explanation has never been empirically examined and, it is still not clear which post characteristic can induce which engagement behavior and why.

Thus, despite the convenience in research design that the oversimplified base model has brought with, it is time to take a step further and dig inside the black box between the stimuli and the behavior. Research on 
marketing communication and traditional advertising has provided us many solid theoretical foundations to start with. For example, the "hierarchy of effects" (HOE) model assumes that consumers perceive, process, and use advertising and other marketing information in a fixed order: first cognitively (i.e., thinking), second affectively (i.e., feeling), and third conatively (i.e., doing) [38-39]. Future research could depend on the HOE model and examine the underlying process between stimuli and behavioral responses.

Except for the HOE model, the stimulus-organismresponse (S-O-R) framework brings new and valuable insights for future research as well. According to the $S$ O-R framework, environmental stimuli (S) lead to the affective and cognitive intermediary states $(\mathrm{O})$, which, in turn, evoke the behavioral responses (R) [40]. The S$\mathrm{O}-\mathrm{R}$ framework has been widely used to study consumer behaviors and could provide a solid basis for investigating the mechanism that explains CEBPSM. For example, previous research has indicated that the consumers' emotional feelings evoked by online contents plays a significant role in determining consumers' engagement with these contents. Berger \& Milkman [30] found that online contents that evoke readers' high-arousal emotions are more viral, regardless of whether the emotions are positive or negative. Therefore, future research could adopt the $S$ O-R framework [40] and investigate the process of consumer engagement with brand posts through a lens of consumers' emotional responses.

\section{Conclusion}

Social media has become an integral part of the marketing communication mix and changed the way that brands and consumers engage with each other. Among the related questions, understanding why consumers engage with brand posts on social media is critically important. This paper contributes to consumer engagement research by providing a literature review and proposing several research agendas for future research. This paper is different from, and it complements previous seminal work [41] in two ways. First, while [41] focused on developing a model of general consumer engagement behavior, this paper specifically focuses on a micro-level investigation of consumer engagement with brand social media posts. Second, instead of viewing consumer engagement as a direct result of stimuli, this paper proposes that, to better understand consumer engagement behavior, future research could examine the mechanism between stimuli (brand post characteristics) and response (consumer engagement behavior).
The results of this paper have many implications. Practically, this paper provides some useful guidelines on how to design the brand posts that enhance consumer engagement. Theoretically, the results of this paper portray a big picture of the current research on consumer engagement with brand posts on social media as well as reveal many agendas that future research could address. That said, this paper is not without limitations. The way we conducted the literature search limited the sample size used within this paper. Future research could extend the literature search by including more databases or using more search keywords.

\section{Reference}

[1] R. Dolan, J. Conduit, J. Fahy, and S. Goodman, "Social media engagement behaviour: a uses and gratifications perspective", Journal of Strategic Marketing, 24(3-4), 2016, pp. 261-277.

[2] A. Gretry, C. Horváth, N. Belei, and A.C. van Riel, "'Don't pretend to be my friend!' When an informal brand communication style backfires on social media", Journal of Business Research, 74, 2017, pp. 77-89.

[3] K. Hutter, J. Hautz, S. Dennhardt, and J. Füller, "The impact of user interactions in social media on brand awareness and purchase intention: the case of MINI on Facebook", Journal of Product \& Brand Management, 22(5/6), 2013, pp. 342-351.

[4] S. Chung, A. Animesh, K. Han, and A. Pinsonneault, "Firms' Social Media Efforts, Consumer Behavior, and Firm Performance: Evidence from Facebook", Proceedings of the 35th International Conference on Information Systems, 2014.

[5] C.K. Coursaris, W. van Osch, and B.A. Balogh, "Informing brand messaging strategies via social media analytics", Online Information Review, 40(1), 2016, pp. 6-24.

[6] R.E. Cruz, J.M. Leonhardt, and T. Pezzuti, "Second Person Pronouns Enhance Consumer Involvement and Brand Attitude", Journal of Interactive Marketing, 39, 2017, pp. 104-116.

[7] L. de Vries, S. Gensler, and P.S. Leeflang, "Effects of traditional advertising and social messages on brandbuilding metrics and customer acquisition", Journal of Marketing, 81(5), 2017, pp. 1-15.

[8] T.F. Wagner, C.V. Baccarella, and K.I. Voigt, "Framing social media communication: Investigating the effects of brand post appeals on user interaction", European Management Journal, 35(5), 2017, pp. 606-616.

[9] A. Kumar, R. Bezawada, R. Rishika, R. Janakiraman, and P.K. Kannan, "From social to sale: The effects of firmgenerated content in social media on customer behavior", Journal of Marketing, 80(1), 2016, pp. 7-25.

[10] D. Lee, K. Hosanagar, and H.S. Nair, "Advertising content and consumer engagement on social media: evidence from Facebook", Management Science, 64(11), 2018, pp. 5105-5131.

[11] eMarketer. "Retailers get bragging rights for Facebook interaction", $\quad$ Retrieved from 
http://www.emarketer.com/Article/Retailers-BraggingRights-Facebook-Interaction/1012313, 2015.

[12] C. Ashley, and T. Tuten, "Creative strategies in social media marketing: An exploratory study of branded social content and consumer engagement", Psychology \& Marketing, 32(1), 2015, pp. 15-27.

[13] D.H. Kim, L. Spiller, and M. Hettche, "Analyzing media types and content orientations in Facebook for global brands", Journal of Research in Interactive Marketing, 9(1), 2015, pp. 4-30.

[14] M. López, M. Sicilia, and P.W. Verlegh, "“Click like if you like it': the effect of directional posts on social network sites", Online Information Review, 41(5), 2017, pp. 672-690.

[15] Marketing Science Institute, Research Priorities 20182020. Marketing Science Institute, Cambridge, Massachusetts, 2018.

[16] I.P. Cvijikj, and F. Michahelles, "Online engagement factors on Facebook brand pages", Social Network Analysis and Mining, 3(4), 2013, pp. 843-861.

[17] L. de Vries, S. Gensler, and P.S. Leeflang, "Popularity of brand posts on brand fan pages: an investigation of the effects of social media marketing", Journal of Interactive Marketing, 26(2), 2012, pp. 83-91.

[18] J. Gutiérrez-Cillán, C. Camarero-Izquierdo, and R. San José-Cabezudo, "How brand post content contributes to user's Facebook brand-page engagement. The experiential route of active participation", $B R Q$ Business Research Quarterly, 20(4), 2017, pp. 258-274.

[19] L. Kwok, and B. Yu, "Spreading social media messages on Facebook: An analysis of restaurant business-toconsumer communications", Cornell Hospitality Quarterly, 54(1), 2013, pp. 84-94.

[20] S.S.I. Lei, S. Pratt, and D. Wang, "Factors influencing customer engagement with branded content in the social network sites of integrated resorts", Asia Pacific Journal of Tourism Research, 22(3), 2017, pp. 316-328.

[21] P. Luarn, Y.F. Lin, and Y.P. Chiu, "Influence of Facebook brand-page posts on online engagement", Online Information Review, 39(4), 2015, pp. 505-519.

[22] F. Sabate, J. Berbegal-Mirabent, A. Cañabate, and P.R. Lebherz, "Factors influencing popularity of branded content in Facebook fan pages", European Management Journal, 32(6), 2014, pp. 1001-1011.

[23] C.D. Schultz, "Proposing to your fans: Which brand post characteristics drive consumer engagement activities on social media brand pages?", Electronic Commerce Research and Applications, 26, 2017, pp. 23-34.

[24] K. Swani, G. Milne, and P.B. Brown, "Spreading the word through likes on Facebook: Evaluating the message strategy effectiveness of Fortune 500 companies", Journal of Research in Interactive Marketing, 7(4), 2013, pp. 269-294.

[25] K. Swani, and G.R. Milne, "Evaluating Facebook brand content popularity for service versus goods offerings", Journal of Business Research, 79, 2017, pp. 123-133.

[26] K. Swani, G.R. Milne, B.P. Brown, A.G. Assaf, and N. Donthu, "What messages to post? Evaluating the popularity of social media communications in business versus consumer markets", Industrial Marketing Management, 62, 2017, pp. 77-87.

[27] M.B. Pinto, and A. Yagnik, "Fit for life: A content analysis of fitness tracker brands use of Facebook in social media marketing", Journal of Brand Management, 24(1), 2017, pp. 49-67.

[28] L.I. Labrecque, "Fostering consumer-brand relationships in social media environments: The role of parasocial interaction", Journal of Interactive Marketing, 28(2), 2014, pp. 134-148.

[29] S. Stieglitz, and L. Dang-Xuan, "Emotions and information diffusion in social media - sentiment of microblogs and sharing behavior", Journal of Management Information Systems, 29(4), 2013, pp. 217248.

[30] J. Berger, and K.L. Milkman, "What makes online content viral?", Journal of Marketing Research, 49(2), 2012, pp. 192-205.

[31] J.U. Islam, J.U. Islam, Z. Rahman, and Z. Rahman, "The transpiring journey of customer engagement research in marketing: a systematic review of the past decade", Management Decision, 54(8), 2016, pp. 2008-2034.

[32] L.D. Hollebeek, M.S. Glynn, and R.J. Brodie, "Consumer brand engagement in social media: Conceptualization, scale development and validation", Journal of Interactive Marketing, 28(2), 2014, pp. 149165.

[33] D.G. Muntinga, M. Moorman, and E.G. Smit, "Introducing COBRAs: Exploring motivations for brandrelated social media use", International Journal of Advertising, 30(1), 2011, pp. 13-46.

[34] T. Duncan, and S.E. Moriarty, "A communication-based marketing model for managing relationships", Journal of Marketing, 62(2), 1998, pp. 1-13.

[35] D.A. Schweidel, and W.W. Moe, "Listening in on social media: A joint model of sentiment and venue format choice", Journal of Marketing Research, 51(4), 2014, pp. 387-402.

[36] D.J. Hughes, M. Rowe, M. Batey, and A. Lee, "A tale of two sites: Twitter vs. Facebook and the personality predictors of social media usage", Computers in Human Behavior, 28(2), 2012, pp. 561-569.

[37] I. Khan, H. Dongping, and A. Wahab, "Does culture matter in effectiveness of social media marketing strategy? An investigation of brand fan pages", Aslib Journal of Information Management, 68(6), 2016, pp. 694-715.

[38] D. Vakratsas, and T. Ambler, "How advertising works: what do we really know?", Journal of Marketing, 63(1), 1999 , pp. 26-43.

[39] T.E. Barry, and D.J. Howard, "A review and critique of the hierarchy of effects in advertising", International Journal of Advertising, 9(2), 1990, pp. 121-135.

[40] A. Mehrabian, and J.A. Russell, An approach to environmental psychology, The MIT Press, Cambridge, MA, 1974.

[41] J. Van Doorn, K.N. Lemon, V. Mittal, S. Nass, D. Pick, P. Pirner, and P.C. Verhoef, "Customer engagement behavior: Theoretical foundations and research directions", Journal of Service Research, 13(3), 2010, pp. 253-266. 